\title{
Molecular Characterization of Virus Infecting Momordica charantia Linn and the Application of Trichoderma viride as Biocontrol Agent in Baccocco Cross River State, Nigeria
}

\author{
D. O. Etim ${ }^{a^{*}}$ and N. I. Okon ${ }^{\text {b }}$ \\ ${ }^{a}$ Department of Botany, University of Calabar, Calabar, Nigeria. \\ ${ }^{b}$ Federal College of Agriculture Ishiagu, Ebonyi, Nigeria.
}

Authors' contributions

This work was carried out in collaboration between both authors. Author DOE designed the study, wrote the protocol and wrote the first draft of the manuscript. Author NIO managed the analyses of the study and read the first draft of the manuscript. Both authors read and approved the final manuscript.

Article Information

DOI: 10.9734/ARRB/2021/v36i1230462

Editor(s):

(1) Dr. Paola Angelini, University of Perugia, Italy.

(2) Dr. Saleha Sadeeqa, Lahore College for Women University, Pakistan.

Reviewers:

(1) Priyadarshani Baliram Kamble, Smt. Meenalben Mehta College, India.

(2) R. Sathyavathi, Adhiyaman Arts and Science College For Women, India.

(3) Jami Nyitan, CSIR-NEIST, India.

Complete Peer review History, details of the editor(s), Reviewers and additional Reviewers are available here: https://www.sdiarticle5.com/review-history/77419

Original Research Article

Received 17 September 2021

Accepted 25 November 2021

Published 13 December 2021

\begin{abstract}
Momordica charantia Linn, commonly called bitter-melon or ampalaya, is a vigorous, tendrilbearing, frost tender, annual vine of the cucurbitacae family reported to play significant role in health and nutrition. Chlorotic spot symptoms were observed on this plant during a visit to some Gardens in Baccocco Cross River State, Nigeria in 2021. The aim of this study was to identify the virus infecting this plant and investigate the ability of Trichoderma viride to control the virus. Infected leaf samples of $M$. charantia were collected and maintained on young seedlings of cucumber through mechanical inoculation which was further used to test the ability of Trichoderma viride as biocontrol agent, the sample was further tested against RT-PCR. Result obtained from Gene sequence analysis revealed $87 \%$ nucleotide sequence identity with Morroccan watermelon mosaic virus. This is the first report of MWMV infecting $M$. charantia in Nigeria. The result further showed that Trichoderma viride was very effective in the control of virus the pathogen.
\end{abstract}


Keywords: Cucurbitacae; gene sequence; Momordica charantia; RT-PCR; Trichoderma virid.

\section{INTRODUCTION}

Momordica charantia Linn, commonly called bitter-melon or ampalaya, is a vigorous, tendrilbearing, frost tender, annual vine of the cucurbitacae family that will grow rapidly to 12 20 ' long in a single growing season. It is native to tropical and sub-tropical parts of Asia and Africa. It was introduced into Hawaii where it has naturalized on several of the islands. It is useful in most metabolic and physiological processes of the human such has lowering the blood sugar in humans and treatment of diabetes. This plant is susceptible to diseases of fungal, bacterial and viral origin [1] and pests, such as the pumpkin caterpillars (Diaphania spp.) and the melon fly (Bactrocera cucurbitae Coquillet). At least 59 viruses have been reported to infect this plant [2]. These viruses have emerged as the most economically significant viruses infecting even other members of the family [3].

Only very few of these viruses have been characterized and identified in Nigeria. For example, [4] have characterized and reported Algerian watermelon mosaic virus infecting Cucurbita pepo in Cross River, Nigeria. [4] further provided a checklist of viruses prevalent in south west of Nigeria. However, Information regarding infection of this plant in Southern Nigeria is lacking.

The fungal genus Trichoderma spp. includes about 100 described species widely distributed throughout the world due to their rapid growth, their ability to use different substrates and to tolerate the presence of different contaminants and environmental conditions [5] Its main current economic interest is based on its use as a biocontrol agent in agriculture and as a producer of enzymes in different industries [5], although in recent years its relevance in other sectors has been increasing, as a promoter of plant growth and tolerance to abiotic stresses [6], biofertilizer [7], source of genes for use in biotechnology [8] or mycoremediator [9]. In its interaction with the plant, Trichoderma mainly behaves as a root endophyte, colonizing only the outermost layers of the root, due to a plant defense response mediated by salicylic acid, which prevents the fungus from reaching the vascular bundles and behaving like a systemic pathogen $[10,11]$. In this way, Trichoderma is also capable of activating systemic plant defenses against the attack of pests and/or pathogens [8]. The ways in which
Trichoderma spores can be applied to crops include preplanting applications to seed or propagation material, incorporation in the soil during seeding or transplant, watering by irrigation or applied as a root drench or dip, the greatest success colonization has been quantified by direct application to seeds and roots [11].

The comparative analysis of the genomes of Trichoderma spp widely used as biocontrol agents in agriculture has shown that mycoparasitism represents the ancestral way of life of the fungal genus. The existence of a greater amount of fungal pathogens in the rhizosphere, together with the production of exudates rich in nutrients, caused Trichoderma to end up interacting with the roots, colonizing them [12]. In this sense, their way of going evolved from mycoparasitism to a more generalist one linked to plants [13].

A visit to some gardens in Baccocco Cross River State, Nigeria revealed chlorotic spots on Momordica charantia (Fig. 1). This study is therefore aimed at characterizing and identifying the virus infecting Momodica charantia and use of Trichoderma viride as biocontrol agent against the virus.

\section{MATERIALS AND METHODS}

\subsection{Collection of Virus Samples}

Infected leave samples showing virus like symptoms were obtained from a Garden in Baccocco in Calabar Municipality of Cross River State and maintained on young seed of cucumber and later transported to the molecular Laboratory of Inquaba West Africa, Ibadan Nigeria for RT-PCR and sequencing. Other seedling of cucumber were reserved for testing the ability of Trichoderma viride to control virus infection.

\subsection{RNA Extraction from Infected Leaf Samples}

Total RNA was extracted from the infected leaf samples of Momordica charantia using the cetyltrimethylammonium bromide (CTAB) protocol as described by [14]. One hundred milligrams of each infected leaf sample was grounded in sterile mortar and pestle in $1 \mathrm{ml}$ extraction buffer (100 mM Tris- $\mathrm{HCl}, \mathrm{pH} 8.0 ; 1.4$ M NaCl; 20 mM EDTA; $2 \%$ CTAB) 


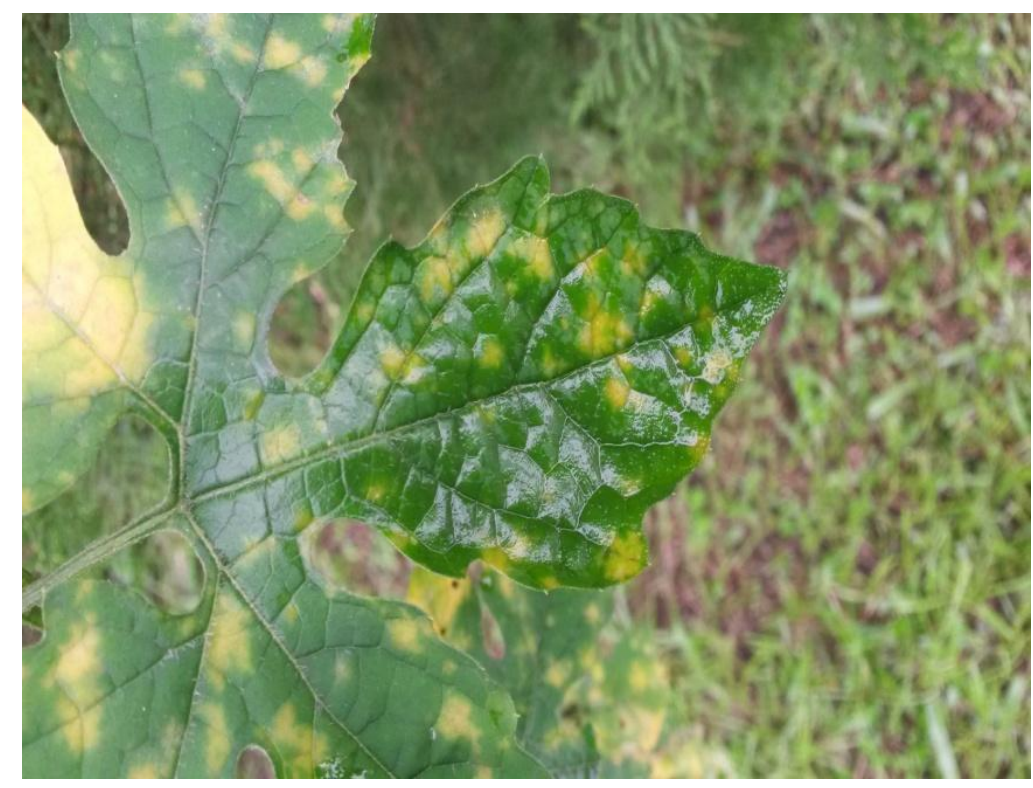

Fig. 1. Chlorotic spots on Momordica charantia

(hexadecetyltrimethylammonium bromide); and $0.4 \% \beta$ - mercaptoethanol, added just before use. Each of the homogenates was poured into a new $1.5 \mathrm{ml}$ Eppendorf tube. The tubes were vortexed briefly, incubated in a $60^{\circ} \mathrm{C}$ water bath for 10 minutes and allowed to cool to room temperature. Then $0.75 \mathrm{ml}$ of phenol choloform isoamyl (25:24:1) was added to each tube containing the homogenate. Each tube was then vortexed vigorously to form an emulsion and then centrifuged at the speed of $12000 \mathrm{rcf}$ for 10 minutes. The supernatant was then transferred to a clean $1.5 \mathrm{ml}$ tube. Three hundred of cold isopropanol was added to the supernatant to precipitate the nucleic acid (RNA) and the mixture was kept at $-80^{\circ} \mathrm{C}$ for 10 minutes. The mixture was centrifuged at $12,000 \mathrm{rcf}$ for $10 \mathrm{~min}$ to precipitate the nucleic acid. The supernatant was discarded and the nucleic acid pellet washed in $500 \mu \mathrm{l}$ of $70 \%$ ethanol and centrifuged at $12,000 \mathrm{rcf}$ for 5-10 minutes. The supernatant was decanted and the resultant nucleic acid pellet was air-dried at room temperature. Nucleic acid pellet was then re-suspended in $50 \mu$ sterile distilled water and used as a template source for reversed transcriptase polymerase chain reaction (RT-PCR). Nucleic acid extracts from the leaves of healthy plants were used as negative control.

\subsection{Reverse Transcriptase Polymerase Chain Reaction (RT-PCR)}

Virus-specific complementary DNA (cDNA) fragments were amplified from total nucleic acid derived from the infected leaf samples by a RT-
PCR method as described by [15]. RT-PCR was performed using the cylindrical inclusion $(\mathrm{Cl})$ primers forward GGIVVIGTIGGIWSIAARTCIAC-3, Reverse ACICCRTTYTCDATDATRTTIGTIGC-3' as described by [16]. The RT-PCR reaction mixture $(50 \mu \mathrm{l})$ consisted of I $\mu$ leach of CICP 5 and CICP 3, $5 x$ Go Taq green buffer (10.0 $\mu \mathrm{l}), \mathrm{MgCl}_{2}$ (3.0), dNTPs $(1.0 \mu \mathrm{l})$, Reverse transcriptase $(0.24 \mu \mathrm{l})$, Taq DNA polymerase (Promega) $(0.24 \mu \mathrm{l})$, sterile distilled water $(30.52 \mu \mathrm{l})$ and nucleic acid from infected leaf sample (1:10 dilution) $(3.0 \mu \mathrm{l})$.

Amplifications were carried out in a GeneAmp 9700 PCR system thermalcycler (Applied Biosystem Inc., USA) using the following thermocyclic conditions; $42^{\circ} \mathrm{C}$ for $30 \mathrm{~min}$ for reverse transcription, $94^{\circ} \mathrm{C}$ for $3 \mathrm{~min}$ for initial denaturing, followed by 40 cycles of denaturing at $94^{\circ} \mathrm{C}$ for $30 \mathrm{sec}$, an annealing step at $40^{\circ} \mathrm{C}$ for $30 \mathrm{~s}$, an extension at $68^{\circ} \mathrm{C}$ for $1 \mathrm{~min}$ and a final extension at $72^{\circ} \mathrm{C}$ for 10 min ended the RT-PCR reaction. The PCR reaction products were separated on $1.5 \%$ agarose gel, subsequently stained with ethidium bromide, visualized in UV light and photographed.

\subsection{Amplicon Purification and Sequencing}

The RT-PCR amplicon for each sample was purified by adding $95 \%$ ethanol to $40 \mu \mathrm{l}$ of the amplicon in a new $1500 \mu \mathrm{l}$ Ependorff tube and the solution was kept in $-80^{\circ} \mathrm{C}$ for 10 minutes. The tube was centrifuged for $10 \mathrm{~min}$ and the 
supernatant discarded. Five hundred of $70 \%$ ethanol was added and centrifuged at maximum speed for $5 \mathrm{~min}$. The supernatant was discarded and the tube was left at room temperature to dry after which the purified CDNA was dissolved in $30 \mu \mathrm{l}$ of sterile distill water. The product was sequenced at Bioscience Laboratory of the International Institute of Tropical Agriculture (IITA) Ibadan.

\subsection{Sequence Analysis}

The sequence identities between the virus under study were established by comparison with known virus sequences in the GenBank available at National Center for Biotechnology Information (NCBI) using the basic local alignment search tool (BLASTn) program (http://www.ncbi.nlm.nih.gov/BLAST/).

\subsection{Preparation of Media for Culturing Trichoderma viride}

Preparation of media for culturing of Trichoderma viride was done using Potato dextrose agar (PDA). 39 grams was poured into $1000 \mathrm{ml}$ conical flask. $1000 \mathrm{ml}$ of distilled water was added and stirred until the solution gave a paste. Non absorbent cotton wool was covered with aluminum foil and used to cork the mouth of the conical flask which was rapped again with aluminum foil up to the neck of the flask. The medium was placed in an autoclave at 121 degrees Celsius for 15 minutes. The medium was allowed to cool before removing from the autoclave and 500 milligrams of Chloraphenicol was added to the solution and allowed to cool before pouring into labeled sterile Petri dishes.

\subsection{Isolation of Trichoderma viride}

Soil samples collected from University of Calabar piggery farm in polyethylene bags were picked up with spatula and dropped in the plates containing PDA solution and labeled accordingly. The inoculated plates were incubated at room temperature of $27 \pm 1^{\circ} \mathrm{C}$ and daily observations were made for emergence of fungal colonies. Colonies formed were subculture to obtain pure cultures of the isolates (Fig. 2).

\subsection{Identification of the Trichoderma viride}

A drop of Lacto phenol in cotton blue was used to stain the slide. Sterilized inoculation needle was used to pick the spores of the fungi from culture plates and Placed on the slide containing the lacto phenol in cotton blue then covered with cover slide for observation and identification under a light microscope. (Olympus Optical Philippines) with magnification (x40). The morphological structures of the fungi were compared with those in the Atlas of Imperfect Fungi by [17] for identification.

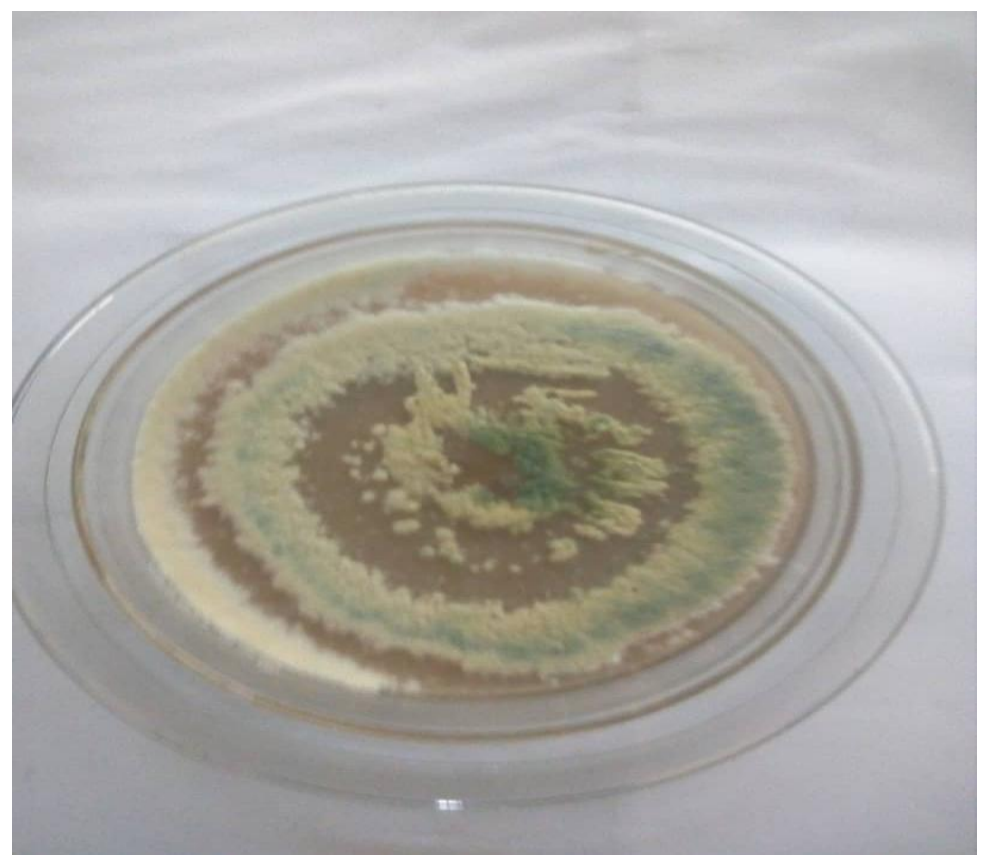

Fig. 2. Colonies of Trichoderma viride 


\subsection{Preparation of Carrier for Trichoderma viride}

Preparation of carrier for Trichoderma viride species was done according to [18]. Three Bima bottles were used for the trial and was sterilized using sodium hypochlorite $(\mathrm{NaOCl})$ solution. The bottles were rinsed in tap water, labeled accordingly and was arranged in a sterilized laboratory bench. Five grams $(5 \mathrm{~g})$ of millet grain was used for the trial, the millet was weighed using ohaus sensitive weighing balance, and was soaked for 24 hours in $500 \mathrm{ml}$ of water before taken to the laboratory. The fermented millet was poured into Bima bottles and well labeled.

Normal sterilization of millet grains inside the bottles was done using autoclave at the range of 121 degrees Celsius or 15 minutes. The millet grains in the sterilized Bima bottles were allowed to cool before a sterilized cork borer was used to bore and pick the fungi in petri dishes and dropped into bottles containing the substrates. Filter paper was used to cover the mouth of the bima bottles and the bored holes of the cover bottles were used to seal the mouth after inoculation. The substrates were taken immediately for inoculation.

\subsection{Inoculation of Trichoderma viride}

Two set of reserved poly bags containing cucumber seedlings, one for inoculation of Trichodrma viride and virus inocula while the second bag for the inoculation of virus inocula only, which invariably served as control. Holes were made in poly bags containing young cucumbers and the prepared millet carrier of 5 grams in Bima bottles containing spores of Trichoderma viride at $2.40 \times 10^{-7}$ spores/ ml were inoculated into the roots of the plants and the inoculated areas were covered with soil. The virus inocula were prepared by triturating symptomatic virus infected leaf tissues of the samples in pre-sterilized cold pestle and mortar in the inoculation buffer and immediately the virus inocula prepared from the symptomatic leaf tissues were inoculated mechanically on carborundum (600 mesh) dusted leaves of the test plants.

\subsection{Inoculation of Virus Inocula}

The second bag was inoculated with only virus inocula using the method stated above for inoculation of virus inocula.

\section{RESULTS}

\subsection{Nucleic Acid Sequencing and Sequence Analysis}

The result obtained after total RNA extraction, RT-PCR and gene sequence revealed fragment of the predicted size, $700 \mathrm{bp}$. Sequence comparisons using BLASTn program available at http://www.ncbi.nlm.nih.gov/BLASTn showed that the virus under study has $87 \%$ nucleotide sequence identity with Moroccan watermelon mosaic virus.

\subsection{Use of Trichoderma viride as Control Agent}

Trichoderma viride, a fungus reported to be effective as a biocontrol agent for virus pathogens was inoculated into the roots of virus infected young seedlings of cucumber and immediately followed by inoculation with virus inocula on leaves of the same plant. The results obtained after three weeks of inoculation revealed that leaves inoculated with the combination of Trichodrma viride and virus inocula showed no symptoms and tested negative to RT-PCR (Fig. 1) while leaves inoculated with virus inocula only revealed mosaic symptoms and tested positive to RT-PCR (Fig. 2).

\section{DISCUSSION}

\subsection{RT-PCR and Gene Sequence Analysis}

The sample was detected by RT-PCR with a predicted size of $700 \mathrm{bp}$ using potyvirus cylindrical inclusion (Cl) primers. The gene sequence analysis revealed $87 \%$ nucleotide sequence identity with Moroccan watermelon mosaic virus. Detection of viruses using RT-PCR has become the most reliable method of virus diagnosis [19]. This result is consistent with the report by [20] who reported the detection of Algerian watermelon mosaic virus, Potato virus $Y$ and Papaya ringspot virus using the RT-PCR procedure and gene sequence analysis. This result also confirms the work of [21] and [22] who employed RT-PCR procedure in the detection of viruses infecting cucurbits. Though some researchers have relied on serological method like DAS-ELISA and ACP-ELISA in plant virus diagnosis in time past however, it can be observed that recent researches have focused on the application of genetic tools in obtaining the true identify of biological entities for which this research also confirmed. 


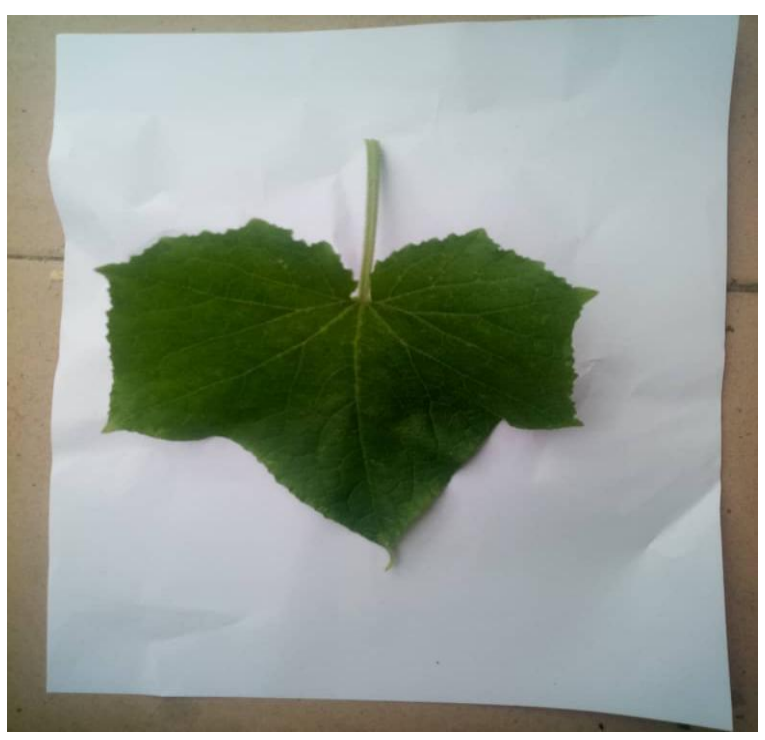

Fig. 3. Cucumber leaf showing no symptoms

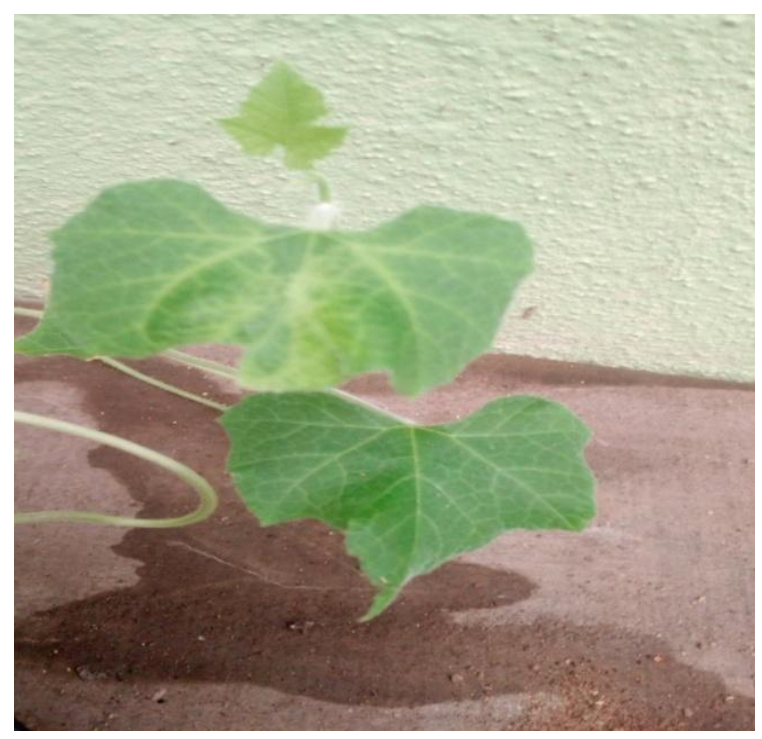

Fig. 4. Mosaic symptoms on cucumber

\subsection{Use of Trichoderma viride as Biocontrol Agent for the Control of Virus Infection}

Several reports have justified the use Trichoderma viride as control agent in controlling several plant pathogens. This study has revealed that leaves of cucumber inoculated with a combination of Trichoderma viride (Control agent) and virus inocula (pathogen) showed no symptoms. Reports by [8] and [23] have revealed that Trichoderma can acts indirectly as a plantendophyte or as a mycoparasite, through the activation of systemic plant defensive responses. Through the colonization of the roots,
Trichoderma is able to activate plant defenses against the attack of pathogens, not only locally, but also systemically through responses mediated by the plant hormones salicylic acid (SA) and jasmonic acid (JA). The use of Trichoderma as a biocontrol agent requires even more studies because it effectiveness make it a sustainable alternative for the future in agricultural plant health [24-27].

\section{CONCLUSION}

This study was carried out to identify virus causing infection on Momordica charantia and the ability of Trichoderma viridae to control the 
virus. Gene sequence analysis revealed $87 \%$ nucleotide sequence identity with Moroccan watermelon mosaic virus. This is the first report of MWMV infecting M. charantia in Nigeria. The result further showed that Trichoderma viridae is very effect in the control of virus pathogens.

\section{COMPETING INTERESTS}

Authors have declared that no competing interests exist.

\section{REFERENCES}

1. Welihinda J, Arvidson G, Gylfe. The insulinreleasing activity of the tropical plant Momordica charantia. Acta Biol Med Ger. 1984;41:1229-1240.

2. Jayasooriya AP, Sakono M, Yukizaki C. Effects of momordica charantia powder on serum glucose levels and various lipid parameters in rats fed with cholesterol-free and cholesterol-enriched diets. J Ethnopharmacol. 2007;72:331-336.

3. Raman A, Lau C. Anti-diabetic properties and phytochemistry of Momordica charantia L (Curcurbitaceae). Phytomed. 1996;2:349-62.

4. Eyong OI, Ekpiken EE, Ubi GM, Alobi AO. Serological and Molecular Characterisation of virus infecting Watermelon (Citrullus lanatus) in Adim-Biase Cross River State, Nigerian. Annual Research and Review in Biology. 2020c;35(11):66-72.

5. Mishra N, Khan SS, Sundari SK. Native isolate of Trichoderma: A biocontrol agent with unique stress tolerance properties. World J. Microbiol. Biotechnol. 2016;32:130.

6. Poveda J. Cyanobacteria in plant health: Biological strategy against abiotic and biotic stresses. Crop Protec. 2020a; 105450.

7. Zhang F, Huo Y, Cobb AB, Luo G, Zhou J, Yang G. Trichoderma biofertilizer links to altered soil chemistry, altered microbial communities, and improved grassland biomass. Front. Microbiol. 2018;9:848.

8. Poveda J. Trichoderma parareesei favors the tolerance of rapeseed (Brassica napus L.) to salinity and drought due to a chorismate mutase. Agronomy. 2020b;10:118.

9. Solanki MK, Kashyap BK, Solanki AC, Malviya MK, Surapathrudu K. Helpful linkages of Trichodermas in the process of mycoremediation and mycorestoration, in:
Ansari, R.A., Mahmood, I. (Eds.) Plant Health Under Biotic Stress. Springer, Singapore. 2019;51-64.

10. Alonso-Ramírez A, Poveda J, Martín I, Hermosa R, Monte E, Nicol' as, C. Salicylic acid prevents Trichoderma harzianum from entering the vascular system of roots. Mol. Plant Pathol. 2014;15:823-831.

11. Woo SL, Ruocco M, Vinale $F$, Nigro $M$, Marra R, Lombardi N. Trichoderma-based products and their widespread use in agriculture. Open Mycol. J. 2014;8:71-126.

12. Kubicek CP, Herrera-Estrella A, SeidlSeiboth V, Martinez DA, Druzhinina IS, Thon M. Comparative genome sequence analysis underscores mycoparasitism as the ancestral life style of Trichoderma. Genome Biol. 2011;12:R40.

Available:https://doi.org/10.1186/gb-201112-4-r40.

13. Kubicek CP, Steindorff AS, Chenthamara K, Manganiello G, Henrissat B, Zhang J. Evolution and comparative genomics of the most common Trichoderma species. BMC Genom. 2019;20:485.

14. Abarshi MM, Mohammed IU, Wasswa P, Hillocks RJ, Holt J, Legg JP, Seal SE, Maruthi MN. Optimization of diagnostic RTPCR protocols and sampling procedures for the reliable and cost-effective detection of Cassava brown streak virus. Journal of Virology Methods, 2010;163(2):353-359.

15. Pappu S, Brand R, Pappu H, Rybicki E, Gough K, Frenkel M, Niblett C. A polymerase chain reaction method adapted for selective amplification and cloning of 3 sequence of potyviral genomes: Application to Dasheen mosaic virus. Journal of Virological Methods. 1993;41:9-20.

16. Ha C, Coombs S, Dale J. Design and application of two novel degenerate primer pairs for the detection and complete genomic characterisation of potyvirus. Archives of Virology. 2008;153:254-60.

17. Barnett HL, Hunter BB. Illustrated genera of imperfect fungi. Minnesota, Burges Publication Press; 1998.

18. Sivan A, Elad Y, Chet I. Biological control of Fusarium crown rot of tomato by Trichodermaharzianum as carrier under field conditions. Plant Diseases. 1984;71:587-592.

19. Usher L, Sivparsad B, Gubba A. Isolation, identification and molecular characterisation of an isolate 
of Watermelon mosaic virus 2 occurring in KwaZulu-Natal, South Africa. International Journal of Virology. 2012;18:10-17.

20. Eyong OI, Ekpiken EE, Iso OA. Annual Research \& Review in Biology. 2021a;36(6):46-54.

21. Helaly HS, Ahmed AA, Awad MA, Soliman AM. Biological and molecular characterization of potato infecting Alfalfa mosaic virus in Egypt. International Journal of Virology. 2012;8:106-113.

22. Eyong OI, Ekpiken EE, Akam DE, Owolabi AT. Identification of Mixed Virus Infection on Trichosanthes cucumerina L. in Akamkpa, Southern Cross River State, Nigeria. Asian Journal of Advances in Agricultural Research. 2021b;15(2):53-58.

23. Poveda J. Use of plant-defense hormones against pathogen-diseases of postharvest fresh produce. Physiol. Mol. Plant Path. 2020c;111:101521.

24. Li YY, Tang J, Fu KH, Gao SG, Wu Q, Chen J. Construction of transgenic
Trichoderma koningi with chit42 of Metarhizium anisopliae and analysis of its activity against the Asian corn borer. J. Environ. Sci. Heal. B. 2012;47:622-630.

25. Jangir $M$, Pathak $R$, Sharma $S$. Trichoderma and its potential applications. In: Singh, D.P., Singh, H.B., Prabha, R. (Eds.), Plant-Microbe Interactions in Agro Ecological Perspectives. Springer, Singapore. 2017;323-339.

26. Li Y, Fu K, Gao S, Wu Q, Fan L, Li Y, Chen J. Impact on bacterial community in midguts of the asian corn borer larvae by transgenic Trichoderma Strain overexpressing a heterologous chit42 gene with chitin-binding domain. PLoS One. 2013;8:e55555.

Available:https://doi.org/10.1080/03601234 .2012 .668455

27. Pitt D, Poole PC. Calcium induced conidiation in penicillin notatum in submerge culture, Transactions British Mycological Society. 1981;219-230.

(C) 2021 Etim and Okon; This is an Open Access article distributed under the terms of the Creative Commons Attribution License (http://creativecommons.org/licenses/by/4.0), which permits unrestricted use, distribution, and reproduction in any medium, provided the original work is properly cited. 